\title{
Review of The New Librarianship Field Guide
}

Gamin G. Bartle, PhD.

WIlliam Paterson University

\begin{abstract}
Review of Lankes, R. D. (2016). The new librarianship field guide. Cambridge, MA: The MIT Press.
\end{abstract}

Keywords: New librarianship, knowledge creation, information literacy, instructional technology

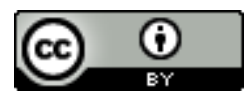

This is an Open Access article distributed under the terms of the Creative Commons Attribution 4.0 International License (http://creativecommons.org/licenses/by/4.0), which permits unrestricted use, distribution, and reproduction in any medium, provided the original work is properly cited. 
In The New Librarianship Field Guide, R. David Lankes argues that -- rather than books, journals, databases, and other types of materials -- a library's community is the collection, and that the function of this community is knowledge creation. His book is something of a manifesto for new librarianship that defines a library as “... a mandated and facilitated space supported by the community, stewarded by librarians, and dedicated to knowledge creation." (p. 96). Lankes encourages a "focus on aspirations, not problems." (p. 63) and cites illiteracy as an example. "Rather than focus on overcoming illiteracy rates, focus on creating an educated community." (p. 63) Such a focus exemplifies the main argument of the Field Guide, namely that librarians are community builders who that create the conditions for knowledge creation.

When a librarian colleague at Drew University asked me to review this book, I suggested that not being a librarian might disqualify me from this task. He countered that an outside perspective would be welcome in this journal, and so I present my review of The New Librarianship Fleld Guide from the standpoint of an instructional technologist. Several years ago, my department (Instructional Technology and User Services) moved into the Drew Library as part of the creation of an Academic Commons. Previous to our relocation, I had begun working with the Drew Library's Reference and Research Department on some aspects of student support. As my department and I settled into our new space, the time was right to deepen our collaboration and begin integrating information literacy and digital fluency. I have subsequently changed jobs, taking the position of Director of Instruction and Research Technology William Paterson University. My WPU office is also located in the Library, such that I can hope to work with the Library toward integrating these two areas. As information literacy and digital fluency, which seem to me to be on parallel tracks, merge ever closer, it is incumbent on librarians and technologists to work in tandem. Knowledge creation cannot happen without well-developed skills in both areas. 
Knowledge is created, Lankes asserts, through conversation. “...if you're in the knowledge business [as librarians are], you're in the conversation business." (p. 24) I propose to expand this particular conversation to include technologists, instructional and otherwise. (Instructional) technologists are also in the knowledge business, and I believe we should be an integral part of the conversations that lead to knowledge creation. Lankes argues that librarians must leave the building to embed themselves in outside organizations. I would add that they should also enter the digital world as fully as possible. Online conversations increasingly require sophisticated information literacy skills. Applying these skills now requires digital fluency. As these skills converge, we must work together to ensure that our community members possess the information and digital skills necessary to navigate and understand our complex, interconnected world. Only then can the conversations that lead to knowledge creation take place in successful, meaningful ways.

A number of the Field Guide's Core Chapter Concepts can be related or adapted to include (instructional) technology. From my standpoint, the parallels could act as a bridge between librarians and technologists. A good example is that of Chapter 12: "A library should be a participatory platform that allows a community to share passions, expertise, and resources."(p. 115) There are any number of participatory platforms in the digital realm. Twitter is one example of many places online where anyone can participate, to "share passions, expertise and resources." (p.115) This is a place where people participate, communicate, and, when we are lucky, create useful knowledge. Perhaps librarians can use it to, as the Core Chapter Concept for Chapter seven describes, “...shape and then enact their communities' definitions of improvement.” (p. 65) Given the bad reputation Twitter has taken on as a place for superficial claims and public arguments, it may seem an unlikely place to "focus on aspirations, not problems." (p. 63) However, there are a lot of constructive and creative conversations on Twitter that may go unnoticed amidst the negativity. I would like to see digital and information literacy skills applied together to raise the level of Twitter conversation, as well as increase awareness that there are constructive things taking place on this platform as well. 
According to Lankes, libraries are not buildings, nor are librarians one-directional purveyors of facts and resources. They are participatory, empowering, and based on living, breathing collections. Lankes deemphasizes library buildings and prioritizes librarians, defining them in his Core Chapter Concept for Chapter 8. Librarians are "principled professionals working with their communities in transformative social engagement." (p. 73) It is in this chapter where I find the parallels between technologists and librarians the most compelling of the Field Guide. In the technology section of this chapter, Lankes writes that librarians should participate in online communities, engage with emerging technologies, support community members in their own engagement with technology tools, and in "creating and maintaining an effective virtual presence." (p. 77) In these ways, librarians can be(come) technologists as appropriate to the stated goal of "transformative social engagement." (p. 73)

I would add that technologists should also work in the way Lankes describes. Of course, technologists are also responsible for maintaining online presences and "imparting technology skills" to community members. It is the way Lankes explains how this is best done that has the most potential to foster true collaboration between librarians and technologists. I think it's fair to say that, in the past, some professionals in both fields tried to "own" specialized knowledge and provided it to their patrons or users rather than collaborating with them and learning together as peers. The directives given to Lankes' librarian readers can be addressed to technologists as well: "Teach by learning, try by collaborating. Your credibility and respect in the community come from your transparency and openness, not by you ability to 'know it all.'” (p. 79)

Rather than knowing it all, librarians are now called upon to know how to connect it all by developing and maintaining relationships with organizations and people well beyond the library building itself. A great example of this kind of connection -- and of "transformative social engagement" -- is the response by librarians in and around Ferguson Missouri. In the summer of 2014, when the start of the school year was delayed after Journal of New Librarianship, 3 (2018) pp. 70-74 10.21173/newlibs/4/14 
the shooting of an unarmed black teenager by a white policeman, it was librarians who took on the challenge. The Florrisant Valley Branch of the Saint Louis County Library and the Ferguson Public Library joined forces with a variety of community organizations to provide not only educational and creative opportunities for the school children, but also lunches. Many children in the school district rely on school lunches to supplement inadequate food supplies in their homes, so the libraries worked with a community group who provided lunches every day until the schools reopened. Museums put on special programming for the children, libraries offered space for teachers to hold classes. All of this happened, Lankes writes in Chapter 1, because “...the library had established and maintained these relationships with the community in the past, so it was able to respond quickly." (p. 3) The community came together in the face of violence and the resulting disorder to facilitate educating their children while the schools weren't able to operate.

Not all libraries or librarians will encounter difficult situations like that in Ferguson in 2014. But the community is fundamental to Lankes's deep thinking about new librarianship. In a chapter 16, he sums up his definition of how -- and even what -- a library collection should be. "The community," he writes, "is the collection." (p. 145) The role of librarians has expanded well beyond the building to encompass other spaces, both real and virtual. Librarians should now be connectors between people and resources, people within and beyond their home institutions, and between communities around the globe. Technologies that allow for global communication and access to resources, and the skills needed to use them, are necessary for the conversations that are at the core of Lankes's thinking.

A final question is exactly how these conversations take place. For Lankes, the answer lies in working and learning together as peers, which requires a fundamental change in how librarians interact with community members. Early in the book, he switches the terminology from patrons to community members intentionally. Librarians no longer "own” knowledge (inasmuch as they ever did), and so the greetings Lankes suggests to replace "How can I help you?” are “'What are you working on today?' or even better 'What's your Journal of New Librarianship, 3 (2018) pp. 70-74 10.21173/newlibs/4/14 
passion?" (p. 120) These questions elicit a community member-focused discussion -- between peers -- with the result of the two people working together toward the common goal introduced by the community member. The librarian identifies and shares resources, human and otherwise, in pursuit of the goal.

In Lankes's view, sharing is taken to another level in “'Human Libraries' [where]... community members offer their passion and expertise as 'human books' on different topics.” (p. 119) These community members are engaged by librarians who ask the question "What is your passion?" as often and in as many contexts as possible, building services around them as appropriate. For example, if a librarian senses a wish for a makerspace, she identifies people who know about 3-D printing, software to create 3-D files, sewing (perhaps for wearable technologies), and other skills that would benefit the community in this endeavor.

Because of the fundamental importance of conversation as a path to knowledge creation, the connections librarians -- together with their (instructional) technologist counterparts -- are, should, and will be making are the basis for success as knowledge-creating conversations continue. It remains to be seen when and how the parallel tracks of information literacy and digital fluency will converge. 